\title{
Honey in the treatment of infantile gastroenteritis
}

\author{
I E HAFFEJEE, A MOOSA
}

\begin{abstract}
A clinical study was undertaken using honey in oral rehydration solution in infants and children with gastroenteritis. The aim was to evaluate the influence of honey on the duration of acute diarrhoea and its value as a glucose substitute in oral rehydration. The results showed that honey shortens the duration of bacterial diarrhoea, does not prolong the duration of non-bacterial diarrhoea, and may safely be used as a substitute for glucose in an oral rehydration solution containing electrolytes. The correct dilution of honey, as well as the presence of electrolytes in the oral rehydration solution, however, must be maintained.
\end{abstract}

\section{Introduction}

Pure honey is bactericidal for many pathogenic organisms, including enteropathogens such as Salmonella spp, Shigella spp, enteropathogenic Escherichia coli, and other Gram negative organisms, ${ }^{1-3}$ and is a readily available source of glucose and fructose. ${ }^{4} \mathrm{~A}$ prospective controlled clinical trial of honey was therefore carried out in infants and children with acute gastroenteritis, the aims being to evaluate its efficacy, if any, $(a)$ in reducing the duration of bacterial diarrhoea and $(b)$ as a substitute for glucose in an electrolyte oral rehydration solution.

\section{Patients and methods}

One hundred and sixty nine infants and children aged 8 days to 11 years who were admitted to the $\mathrm{R} \mathrm{K} \mathrm{Khan} \mathrm{Hospital,} \mathrm{Durban,} \mathrm{with}$ gastroenteritis were entered into the trial. Gastroenteritis was defined as the passage of three or more loose or watery stools per 24 hours with or without vomiting. The patients were randomly assigned to one of two treatment groups.

Group 1 (controls) received routine management of diarrhoea. This comprised oral fluid only or oral and intravenous fluids containing glucose and electrolytes, the oral rehydration solution being composed of glucose $111 \mathrm{mmol} / 1(2.0 \mathrm{~g} / 100 \mathrm{ml})$, sodium $48 \mathrm{mmol}(\mathrm{mEq}) / 1$, potassium $28 \mathrm{mmol}(\mathrm{mEq}) / 1$, and chloride $76 \mathrm{mmol}(\mathrm{mEq}) / 1$, based on the recommendations of $\mathrm{WHO} / \mathrm{UNICEF}^{5}$ but with a lower sodium concentration to obviate hypernatraemia. ${ }^{6}$ All patients received the oral rehydration solution, intravenous fluid being added for severe $(7 \cdot 5-10.0 \%)$ dehydration or intractable vomiting.

Group 2 (honey treated group)-These patients also received either oral fluid only or oral and intravenous fluids depending on the severity of dehydration and the presence of intractable vomiting. Instead of glucose, however, the oral rehydration solution contained $50 \mathrm{ml}$ pure honey per litre, the electrolyte content being identical with that in group 1 . Roughly $70-80 \%$ of honey is composed of glucose and fructose in an approximate ratio of $1: 1,{ }^{4}$ so the glucose concentration of the solution was also $111 \mathrm{mmol} / \mathrm{l}$. Antibiotics were given only if there was a concurrent infection elsewhere (29 patients in group 1, 27 in group 2) or if the patient appeared septicaemic with a high fever (seven in

Department of Paediatrics and Child Health, Faculty of Medicine, University of Natal, Durban, South Africa

I E HAFFEJEE, MFGP(SA), FCP(PAED)(SA), consultant paediatrician and senior lecturer

A MOOSA, MD, FRCP, professor and head

Correspondence to: Dr I E Haffejee, Department of Paediatrics and Child Health, Faculty of Medicine, PO Box 17039, Congella 4013, South Africa. group 1, three in group 2). No antidiarrhoeal preparations or antiemetic drugs were used in any patient.

Stools were examined in most patients, investigations comprising microscopy for parasites; culture for pathogenic bacteria; culture in Butzler's medium at $42^{\circ} \mathrm{C}$ over 48 hours for Campylobacter spp ${ }^{7}$; enzyme linked immunosorbent assay for human rotavirus using the Rotazyme $\mathrm{kit}^{8}$; and a Clinitest for detecting reducing substances. The Clinitest was done within six hours of admission and, in 54 cases, on alternate days thereafter, a reading of $0.75 \%(++)$ or higher being regarded as positive. ${ }^{9}$ Plasma electrolyte concentrations were measured on admission in most patients and subsequently on days 2 and 3 .

"Recovery time" was defined as the number of hours from initiation of treatment to when normal soft stools were passed, with the patient showing normal hydration and satisfactory weight gain. "Rehydration time" was defined as the number of hours from initiation of treatment to when the patient showed normal hydration (as judged by normal skin turgor, tongue, eyeballs, and fontanelle and a normal mental state) but with the diarrhoea not necessarily having resolved.

Student's $t$ test was applied to the data, which were subjected to logarithmic transformation and found to be normally distributed. Levene's test was employed to confirm that the groups had equal variances after transformation. ${ }^{10}$

\section{Results}

Of the 169 patients, 89 were assigned to receive routine management of their diarrhoea (group 1) and 80 to receive honey (group 2). The mean ages of the two groups were 18.8 (1SD 26.2) and $13.5(5.2)$ months, respectively, and the mean age of the whole series 16.3 $(21 \cdot 8)$ months. Most of the children $(143 ; 84.6 \%$ ) fell into the $0-24$ month age group. The overall male to female ratio was also comparable in the two treatment groups $(1.23$ and 1.50$)$, the overall ratio being 1.35 .

From a total of 121 patients whose stools were tested for human rotavirus by enzyme linked immunosorbent assay, $42(34.7 \%)$ were positive (23 in group 1, 19 in group 2). Bacteriological cultures were positive in $36(26.3 \%)$ of 137 patients (18 in each treatment group) and grew Salmonella spp (10), Shigella spp (17), enteropathogenic E coli (8), and Klebsiella (1). Cultures for Campylobacter spp were negative in all 137 patients in whom this investigation was done. Only two patients had intestinal parasites: one control patient had ascariasis, and one honey treated patient was infected with both ascaris and Trichuris trichiura. The causative agent could not be identified in 46 $(38 \%)$ of 121 patients who had all four tests performed.

Recovery from diarrhoea-With the entire series of 169 patients taken as a whole, irrespective of aetiology, the mean recovery times for the control and honey treated groups were almost identical at $64.66(1 \mathrm{SD} 49.65)$ and $63.91(46.03)$ hours $(\mathrm{p}=0.74)$. One patient in the honey treated group, but none of the controls, had diarrhoea lasting 10 days. When the 36 patients with bacterial gastroenteritis were considered as a separate group, however, the mean recovery times were $93.19(60.02)$ hours for the controls compared with 58.00 (34.54) hours for those receiving honey. This difference was statistically significant $(p<0.05)$ (table). Antibiotics had been given to eight con-

Recovery from diarrhoea

\begin{tabular}{|c|c|c|c|}
\hline & Controls & $\begin{array}{l}\text { Honey treated } \\
\text { patients }\end{array}$ & $\begin{array}{c}\mathrm{p} \text { Value } \\
(t \text { test with } \\
\log \text { transformed } \\
\text { data })\end{array}$ \\
\hline \multirow{2}{*}{$\begin{array}{l}\text { No } \\
\text { Mean recovery time in hours } \\
\text { (1 SD) }\end{array}$} & 89 & ${ }_{80}$ All cases & \\
\hline & $64.66(49.65)$ & $63.91(46.03)$ & 0.7431 \\
\hline \multirow{2}{*}{$\begin{array}{l}\text { No } \\
\text { Mean recovery time in hours } \\
\quad(1 \text { SD })\end{array}$} & 18 & $\begin{array}{l}\text { Bacterial diarrho } \\
\quad 18\end{array}$ & \\
\hline & $93.19(60.02)$ & $58 \cdot 0(34 \cdot 54)$ & $0.0257^{*}$ \\
\hline
\end{tabular}

*Difference significant. 
trols and five honey treated patients with bacterial diarrhoea for indications other than the intestinal infection.

Rehydration time-Forty five patients in group 1 and 39 in group 2 received oral rehydration solution only. Their mean rehydration times (14.03 (1SD 10.08) hours and 12.04 (5.54) hours respectively) were not significantly different. Of the 85 patients who received oral and intravenous fluids concurrently, the controls $(n=44)$ took a mean of $23.22(22.88)$ hours to achieve a state of normal hydration and the honey treated group $(n=41)$ a mean of $17.56(12.04)$ hours. This difference also was not significant.

Reducing substances in stools-Of the 79 patients whose stools were examined for reducing substances within six hours of admission, 13 (six controls, seven honey treated patients) gave a positive result. Fifty four patients had the test repeated on alternate days thereafter, and in only three (two controls, one honey treated) with no reducing substances originally did the test result become positive during the illness. Eleven others (nine controls, two honey treated) had a positive test result for reducing substances between days 3 and 6 of the illness; these patients had not had the test done on admission.

Plasma sodium concentrations - The mean plasma sodium concentration on or soon after admission in 73 controls was 136.5 (1SD 4.9) $\mathrm{mmol} / \mathrm{l}$ (range $124-150 \mathrm{mmol} / \mathrm{l}$ ). After rehydration the mean concentration was $137 \cdot 4(2 \cdot 2) \mathrm{mmol} / 1$ (range $134-140 \mathrm{mmol} / \mathrm{l}$ ). In the honey treated group $(n=67)$ the mean initial plasma sodium concentration was $135 \cdot 4(16 \cdot 1) \mathrm{mmol} / \mathrm{l}$ (range $120-154 \mathrm{mmol} / \mathrm{l}$ ). After rehydration the mean concentration was $137 \cdot 7(5 \cdot 3) \mathrm{mmol} / \mathrm{l}$ (range $123-144 \mathrm{mmol} / \mathrm{l}$ ). These differences were not significant.

\section{Discussion}

Two important points emerge from these findings. Firstly, honey shortens the duration of diarrhoea in patients with bacterial gastroenteritis caused by organisms such as Salmonella, Shigella, and $E$ coli. A possible explanation may be the known antibacterial properties of honey detected in vitro, ${ }^{1-3}$ though we did not repeat the stool cultures to see whether these bacteria had been eliminated because in most cases the result of the positive culture became available only after the patient had made a clinical recovery and been discharged. Use of antibiotics, which were given to some patients for indications other than the gastroenteritis, cannot explain the difference in outcome; in fact, more controls received these than did honey treated patients. In non-bacterial gastroenteritis honey had the same effect as glucose on the duration of the diarrhoea.

Secondly, oral honey may safely be used as a substitute for pure glucose in oral rehydration solutions, provided that these contain electrolytes in the currently recommended concentrations $^{6} 1112$ and that the concentration of honey provides 111 mmol of each of glucose and fructose per litre $(2.0 \mathrm{~g} / 100 \mathrm{ml})$. Such a rehydrating fluid is as effective as a solution containing pure glucose and electrolytes.

Since pure honey has a high sugar content it could be used to promote sodium and water absorption from the bowel in a manner analogous to the use of oral rice water ${ }^{13}$ and sucrose. ${ }^{14} 15$ Seventy to eighty per cent of honey is composed of fructose and glucose, the ratio of fructose to glucose being slightly greater than $1: 1 .^{416}$ All oral fluids containing glucose and electrolytes are used for their sodium coupled active absorption of glucose to rehydrate patients. ${ }^{17}$ The dose of honey used in our studythat is, $50 \mathrm{ml}$ per litre of oral fluid containing $48 \mathrm{mmol}$ sodium, $28 \mathrm{mmol}$ potassium, and $76 \mathrm{mmol}$ chloride per litre-provided $111 \mathrm{mmol}$ of each of glucose and fructose per litre. Fructose, which is absorbed by facilitated diffusion rather than by active transport and is not coupled to sodium ions, ${ }^{18}$ would be expected to promote water absorption without augmenting absorption of sodium. This is borne out by the absence of hypernatraemia in patients receiving the honey-electrolyte solution. Honey $100 \mathrm{~g}$ contains $7 \mathrm{mg}$ sodium and $51 \mathrm{mg}$ potassium. ${ }^{19}$ This resulted in an additional $0.25 \mathrm{mmol}$ sodium and $0.63 \mathrm{mmol}$ potassium in each litre of oral fluid containing honey. These are negligible amounts and would not be expected materially to influence the outcome. Furthermore, despite its high sugar content honey does not result in osmotic diarrhoea when used in the proper dilution in oral rehydrating solution. This is confirmed by our results, which showed that the vast majority of patients receiving honey did not have reducing substances detectable in the stools during treatment. Our oral rehydration solutions containing honey had a total glucose-fructose concentration of about $220 \mathrm{mmol} / \mathrm{l}$ $(4.0 \mathrm{~g} / 100 \mathrm{ml})$, and even this did not appear to aggravate the diarrhoea.

Our results show that honey given with oral rehydration fluid shortens the duration of bacterial diarrhoea and may safely be used as a substitute for glucose-provided, of course, that the solution contains electrolytes. Diarrhoea of non-bacterial causes is not prolonged in patients treated with honey, which is safe, non-allergenic, and readily available in most communities and, when used as described, is just as efficient as glucose in promoting sodium and water absorption from the gut.

Other points to emerge were the high proportion $(84.6 \%)$ of infants in the $0-24$ month age group and the fact that only a small proportion of patients passed reducing substances in their stools, irrespective of whether they were receiving honey or not. Both these findings agree with those of other workers, who have observed that infants in the 6-24 month age group are the most susceptible to human rotavirus and that sugar intolerance is not a feature of this illness. ${ }^{20}$

Expert statistical advice was given by Dr P J Becker, of the Institute for Biostatistics of the South African Medical Research Council.

\section{References}

1 Cavanah D, Beazley J, Ostapowicz F. Radical operation for carcinoma of the vulva a new approach to wound healing. Fournal of Obstetrics and Gynaecology

2 Ibrahim AS. Antibacterial action of honey. Proceedings of the first internationa conference on Islamic medicine, Kuwait, January 1981. Bulletin of Islamic medicine. 2nd ed. Vol 1. Kuwait: Ministry of Health, 1981:363-5.

3 Jeddar A, Kharsany A, Ramsaroop UG, Bhamjee A, Haffejee IE, Moosa A The anti-bacterial action of honey: an in vitro study. S Afr Med $\mathcal{f} 1985 ; 67$ : 257-8.

4 British Pharmaceutical Society of Great Britain. British pharmaceutical codex. 11th ed. London: Pharmaceutical Press, 1979:415.

World Health Organisation. Treatment and prevention of dehydration in diarrhoeal diseases. A guide for use at the primary level. Geneva: WHO, 1976. diarrhoea. Mahalanabis D, Jalan KN, et al. Oral rehydration in infantile Dis Child 1978;53:284-9. 1978;i:604-5.

作 , et al. Enzyme-linked immuno assay (ELISA) for detection of human reovirus-like agent of infantile gastroenteritis. Lance 1977;ii:263-7.

9 Anderson CM, Burke V, eds. Disorders of carbohydrate digestion and absorption In: Paediatric gastroenterology. Oxford, Melbourne: Blackwell Scientific
Publications, 1975:199-217. 1981 .

11 Nichols BL, Soriano HA. A critique of oral therapy of dehydration due to diarrheal syndromes. Am $\mathcal{F}$ Clin Nutr 1977;30:1457-72.

2 Finberg $L$. The role of electrolyte-glucose solutions in hydration for childreninternational and domestic aspects. $\mathcal{F}$ Pediatr 1980;96:51-4.

13 Patra FC, Mahalanabis D, Jalan KN, Sen A, Banerjee P. Is oral rice-electrolyte solution superior to glucose electrolyte solution in infantile diarrhoea ? Arch Dis Child 1982;57:910-2.

14 Nalin DR. Sucrose in oral therapy for cholera and related diarrhoea. Lancet 1975; : :1400-2.

15 Chatteriee A, Mahalanabis D, Jalan KN, et al. Evaluation of a sucrose/electrolyte solution for oral rehydration in acute infantile diarrhoea. Lancet $1977 ; \mathrm{i}: 1333-5$. Reynolds JEF, ed. Martindale; the extra pharmacopoeia. 28th ed. London: Pharmaceutical Press, 1982:53.

17 Hirschhorn N, Kinzie JL, Sachar DB, et al. Decrease in net stool output in cholera during intestinal perfusion with glucose-containing solutions. $N$ Engl $\mathcal{f} M e d$ 1968;279:176-81.

18 Ganong WF, ed. Gastrointestinal function: digestion and absorption. In : Review of medical physiology. 10th ed. Los Altos, California: Lange Medical Publications, 1981:371-9.

19 Diem K, Lentner C, eds. Scientific tables. 7th ed. Basle: Ciba-Geigy, 1970:509. Medicine i $1979 ; 5: 248-55$.

(Accepted 28 March 1985) 